\title{
新技術情報 动
}

\section{レーザ粒度測定装置用センサ}

金属粉末, セラミック原料, 食品顆粒，塗料，スプ レーなど，固体や液体の粒子がかかわる産業分野は 極めて広い。微粉炭や燃料油の噴霧の粒径が燃焼特 性に影響を与えるのと同様，粒子の大きさは製品の 特性, 品質や性能, あるいは味覚などに影響を与える ので, その測定は重要である。この十数年をみると， 新しい粒状物質の開発に伴う粒度計測の需要の増大 と，レーザやマイクロコンピュータなどが容易に利 用できるようになったこととが相まって，粒子によ る光の散乱現象を利用する粒度測定装置の開発が進 み，その幾つかは広く使用されるまでに発展した。

回折式粒度計と一般に呼ばれる装置は，その代表 であろう。これは, 前方の比較的狭い角度内に散乱 される光の強度分布（パターン）が粒径に応じて変 化することを利用するものである。図 1 に示すよう に, 光源には出力数ミリワットのレーザが用いられ, 測定部の粒子からの散乱光は前方の受光レンズに よって集められる。多重散乱の影響が無視できる場 合には，受光レンズの焦点面での光の強度パターン は，個々の粒子からの散乱強度パ夕ーンの重ね合わ せであるので，測定された強度分布から粒子群の粒 度分布を決定することができる。

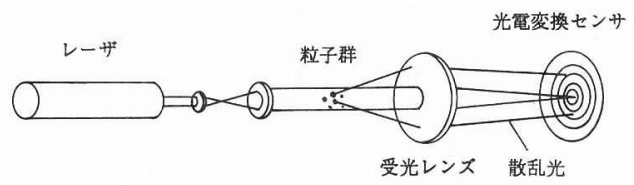

図 1 光学系の概要
航空宇宙技術研究所 林茂

（瞬時）などの優れた特性を備えるに至った。

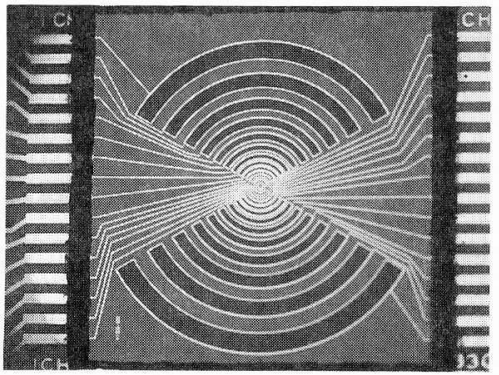

図 2 多重環状光電変換センサ

図 2 は著者らが開発した多重環状光電センサであ る。シリコン基板上に, 散乱強度パターンの特徵的 変化を検出するための30個の部分環状素子が，光軸 合せのための 2 個の素子と同心に配列されている。 粒度区分は分解能の点から対数的に設定されるので, それに対応して最適設計すると，中心部の素子の寸 法は幅, 径とも急激に小さくなる。素子と素子との 隙間は半径方向には無いのが望ましい。一方, クロ ストーク（ある素子に入射した光によって発生した フォトキャリアが隣接素子へ洩れ込む現象）防止の

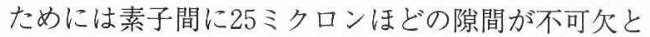
される。また, 応答性の点から, 素子の内部ではな く，外縁周に沿うように電極を付けたい。このよう な相入れない要求を満たすために, 偶数番と奇数番 の素子を，上下に交互に配置した。このようにする

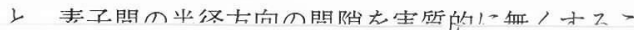

